\title{
Transcultural aspects of family planning and reproductive healthcare
}

Law, politics and economics are as much to do with patients' healthcare as medicine. Racial or ethnic discrimination is illegal in the UK under the Race Relations Act 1976. Since 2nd October 2000, religious and cultural discrimination (or lack of consideration or respect) has also become illegal under the Human Rights Act 1998, Article 9, which ensures that everyone has the right to freedom of thought, conscience and religion. ${ }^{1}$ As a result, persons who are victims of a violation of a convention (human) right by a public authority can bring proceedings in the appropriate UK Courts. The Human Rights Act 1998 has now been fully incorporated into UK law and judges have been given training over the past 2 years. It should be remembered that all doctors - GPs, obstetricians, gynaecologists and family planning specialists - are public authorities, and are answerable to these laws.

Under the Race Relations Act 1976, the ethnic majority in Britain consists of only three major groups: English, Scottish and Welsh. All others are ethnic minorities. A political approach is that doctors should deal with ethnic majority and minority groups separately, which in some parts of Britain is already happening. Another approach, which I proposed in 1989, in my book TransculturalMedicine, is the transcultural approach. This approach means dealing with patients from all cultures, religions and ethnicities appropriately, with due regard to their distinctions and differing needs, which require different provisions. ${ }^{2}$ Let us treat all groups equally and recognise their differences in relation to family planning and reproductive healthcare.

In tackling the cultural boundaries, it is prudent to remember that patients, health professionals and managers come from three main cultures: western, eastern and westernised eastern. They all have different customs, appropriate to their respective cultures, and these customs may interact. For example, courtship (friendship before marriage) is a western custom. It is strongly discouraged in the eastern culture. There are good reasons why both cultures are right in the context of their own backgrounds. The western culture considers courtship as an essential component of a love marriage, but the eastern culture considers it as an obstacle to an arranged marriage. It is essential that:

- all health professionals show respect to both points of view which their clients (patients) may hold separately

- each person should be treated according to their expressed wish, even if it differs from the health professional's point of view

- health professionals from an eastern culture, although mostly westernised, may not be westernised enough. They should be encouraged to understand the cultural needs of western patients in the same way that it is important for western health professionals to respect the wishes of eastern patients.

Specific to reproductive healthcare is the cultural importance of using the left hand. The vast majority of people are right-handed. Whereas a western person would use either hand to do all tasks, this practice does not apply to an eastern person. In the east, the right hand is reserved for eating food, shaking hands, or counting money and only the left hand is used to touch the genital and anal regions. This is an ancient habit, which can be described as akin to barrier nursing. Among eastern right-handed people, a woman would find it difficult to insert a pessary, diaphragm, spermicidal cream or female condom, and would need more time. An eastern man would find it difficult to put on a condom, particularly at the height of excitement. However, the reverse is true for eastern lefthanded people. One cultural trap may be to joke about such matters, but if overdone this can lead to a disastrous consultation. Transcultural understanding is vital for health professionals and patients alike.

Religious beliefs must be taken into account when choosing a contraceptive method or a safe-sex programme. Six major religions, listed alphabetically, include Buddhism, Christianity, Hinduism, Islam, Judaism and Sikhism. Caring attitudes and scientific skills go hand in hand in patient care. Three religious convictions, held by devout followers, should be remembered:

- Judaism, Islam and Catholicism promote the importance and sanctity of procreation and condemn the use of condoms (and masturbation) because each sperm is considered as a potential human being. This conviction has a profound implication on safe-sex programmes and family planning services in Britain and world-wide.

- Menstruation exempts a woman from religious duties and many family tasks in almost all religions, particularly in Judaism, Islam, Hinduism and Sikhism. Spotting or vaginal bleeding due to a combined pill, progestogen-only pill, progestogen injections, intrauterine device or during cervical screening may be interpreted by a devoutly religious woman as menstruation. Health professionals should inform them before-hand that this vaginal bleeding is not a natural menstrual bleeding, therefore it should not forbid them from religious tasks. However, she should still be advised to consult a religious leader to be certain. Some Muslim, Hindu or Sikh women going for religious journeys/pilgrimages may request a doctor to give a course of a combined pill so as to postpone menstrual blood flow, which may occur right in the middle of a religious ceremony. They should be helped.

- Except Christianity, all other five major religions require their followers to observe sex-segregation. No male doctor should carry out a vaginal examination of such a religious woman. Family planning specialist nurses should be contacted, where a lady doctor is not available, to see such a woman. No woman doctor in a genitourinary medicine clinic should examine a man against his wishes.

It should not be under-estimated that when a religious taboo is broken or has to be broken, the person will feel guilty, dirty and experience spiritual pain. The Human Rights Act 1998, Article 9, ensures a person's right to freedom of thought, conscience and religion. No doctor has the right to cause guilt, dirty feelings or spiritual pain in a patient.

Finally, ethnic characteristics of every individual should be taken into account for medical and medico-legal reasons. 
There are four races (ethnicities) according to anthropologists: Caucasians (whites), Asiatics (Asians from India, Pakistan, Bangladesh and Sri Lanka), Black people (Africans and Caribbeans) and Orientals (from China, Japan and SE Asia).

It is widely known that cystic fibrosis is more common among whites and sickle cell disease is more prevalent among blacks. Whereas European doctors may have less expertise in prescribing appropriate methods of contraception for women with sickle cell disease, many overseas-trained doctors may have less expertise in prescribing suitable contraception for young European women with cystic fibrosis. Expecting that knowledge may be lacking in these groups of doctors and nurses, and providing appropriate training, can successfully narrow the education-gap.
To deny transcultural, religious and ethnic needs and their diversity is akin to denying the law of gravity. Where a health professional of one ethnic group is dealing with a patient from another, it is vital to understand each other's background and to be prepared to negotiate. After all, the patient is the most important person in medicine.

Bashir Qureshi, FRCGP, MFFP, DCH, AFOM, GP in West
London, author of 'Transcultural Medicine', and an expert

Bashir Qureshi, FRCGP, MFFP, DCH, AFOM, GP in West
London, author of 'Transcultural Medicine', and an expert witness, Tel/Fax: 02085704008

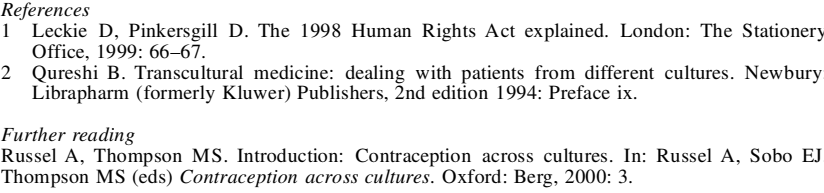

\section{What's in a name?}

2001 brings a new title for the Journal; a name that acknowledges the increasing international readership and the broader remit of reproductive health care. The words 'family planning' have been retained in keeping with the title of the Faculty. However, at every meeting I have attended recently I have noted a growing groundswell of dissention to the use of this term. Is it an outmoded concept, inappropriate for the $21^{\text {st }}$ century? If we drop the concept of planning families, are we colluding with irresponsible attitudes that deny the possibility that recreational heterosexual penetrative sex still carries procreational potential, despite contraception? Is the best method of contraception is still to say 'no'? Do young people understand the word contraception? Is the older generation ready to enter the portals of a 'sexual health' service without embarrassment? What will this emerging specialty be called in 10 years time? How will it evolve over the next 10 years, and how important will the name be in shaping that evolution? Please join the debate and send your thoughts to journal@ffprhc.org.uk

\section{Fran Reader}

Honorary Editor

Journal of Family Planning and Reproductive Health Care

\section{The Journal of Family Planning and Reproductive Health Care - Peer Reviewers 2000}

Dr Lesley Bacon, Dr Urszula Bankowska, Dr Deborah Beere, Dr Anne Bennett, Dr Sharon Bodard, Mrs Walli Bounds, Mr Peter Bowen-Simpkin, Dr Nanas Callander, Dr Jane Campbell, Dr Elizabeth Carlin, Dr Susan Carr, Dr Ruth Clancy, Dr Michael L Cox, Dr Margaret Curtis, Dr Elizabeth

Devonald, Prof. Lindsay Edouard, Mr Hani W Fawzi, Mr Babatunde A Gbolade, Dr Suanda Gupta, Dr Kate Guthrie, Prof. Phil Hannaford, Mr Guy Hartfall, Dr David Hicks, Dr Rebecca Hobbs, Dr Barbara Hollingworth, Dr Jennifer Hopwood, Dr Rachel Joce, Dr Louise Kane, Dr Brian Kebble, Dr Rosemary Kirkman, Dr Kate Kirkwood, Dr Meera Kishen, Dr Ali Kubba, Dr Katie Law, Dr Emma Manson, Dr Diana Mansour, Dr Asun de Marguiegui, Dr Caroline Marfleet, Dr Martin Marshall, Dr John McEwan, Miss Heather Mellows, Miss Angela Mills, Dr Judy Murty, Dr Kate Nash, Dr Robert Nightgale, Dr Paul O’Brien, Mr Anthony Parsons, Dr Mary Poulton, Dr Catriona Reid, Dr Helen Ribbans, Dr Sam Rowlands, Dr Caroline Sadler, Dr Mary Scott, Dr Stephen Searle, Dr Jacqueline Sherrard, Dr Connie Smith, Dr Lindsay Smith, Dr Sue Smith, Dr Karen Stein, Dr Imogen Stephens, Mr Peter Stewart, Dr Petrus Steyn, Dr Anne Szarewski, Dr K Joo Thong, Dr Catherine Tupper, Dr Gillian Vanhegan, Dr Martyn Walling, Dr Gillian Wandless, Dr Ann Webb, Dr Chris Wilkinson. 